\title{
Cast iron deterioration with time in various aqueous salt solutions
}

\author{
RITA MEHRA* and ADITI SONI \\ Department of Applied Chemistry, Maharshi Dayanand Saraswati University, Ajmer 305 009, India
}

MS received 4 June 2001; revised 21 December 2001

\begin{abstract}
The changes with time in the corrosion rate and corrosion current density on a cast iron electrode in various aqueous salt solutions have been carried out using total immersion test and potentiostatic polarization curves. The concentration of salts taken is expected to be present in potable water. The relative behaviour of these salts towards corrosion has also been studied, which is found to be different from previous studies. The total immersion test parameters viz. weight loss, corrosion rate as well as potentiostatic parameters, open circuit potential, $I_{\text {corr }}$, Tafel slopes, corrosion rate, have been calculated by standard methods. Besides these the relative increase in corrosion rate with time as well as the percentage to which corrosion rate should be decreased so as to provide protection towards corrosion have also been calculated. It was found that $\mathrm{KCl}$ and $\mathrm{NaCl}$ are major contributors than $\mathrm{MnSO}_{4}, \mathrm{~Pb}\left(\mathrm{NO}_{3}\right)_{2}$, $\mathrm{KI}$ and $\mathrm{KBr}$. The relative increase in corrosion is high in $\mathrm{KBr}, \mathrm{KI}, \mathrm{NaNO}_{3}, \mathrm{CaCl}_{2}$, and less in $\mathrm{Pb}\left(\mathrm{NO}_{3}\right)_{2}, \mathrm{NaHCO}_{3}$ and $\mathrm{CaCO}_{3}$ test solutions. For the reliability of results the data has been statistically analysed.
\end{abstract}

Keywords. Corrosion; cast iron; water; salts.

\section{Introduction}

Cast iron is widely used for water carrying purposes besides mild steel and other metals. The extent and cost of damage caused by leakage in domestic water pipes has been rising during recent years. The use of cast iron in potable water supplies in buildings is now essentially limited to the incoming main water supplies (Gedge 1993). Within buildings themselves cast iron is now generally used only for pump and valve bodies. The corrosion resistance of cast iron is however relatively better. Various studies have been carried out for determination of corrosive behaviour of cast iron in acid, its salt aqueous solutions at high concentration of salts as well as in water supply systems (Siiry 1978; Andrzejaczek 1979; Weber 1979). Corrosive behaviour of metals in aqueous solutions is mainly determined by dissolved salts and oxygen (Dubey et al 1997). In order to minimize corrosion problem in water supply system it is important to identify the mechanism of corrosion rate of ions with cast iron, the extent to which they contribute to corrosion in potable water as well as their threshold limiting values to which the corrosion rate should be minimized in order to provide excellent corrosion resistance (Gour et al 1994).

\section{Experimental}

The $2 \times 2 \mathrm{~cm}^{2}$ analysed cast iron specimens of thickness $0.5 \mathrm{~cm}$ were used. The specimens were cast in the die by appropriate casting procedure (Rao 1980; Kumar et al

\footnotetext{
*Author for correspondence
}

1991). The chemical composition used was $\mathrm{C}-3 \cdot 26 \%$, $\mathrm{S}-$ $0.10 \%, \mathrm{Si}-2.25 \%, \mathrm{Mn}-0.59 \%, \mathrm{P}-0.06 \%$ besides iron, as analysed by standard method (Vogel 1964; Jain 1986). After casting, the surfaces were smoothened and a hole was drilled near the upper edge. The specimens were cleaned by buffing, degreased in benzene, washed using $50 \%$ acetone, dried, marked and weighed to a constant weight before exposing to the corrosive medium. These were suspended by a glass hook in a beaker filled with test solution, for different duration of immersions: 24, 72, 120, 192, 240 and $360 \mathrm{~h}$. After definite period of exposure, specimens were removed and cleaned as per recommended procedure (Mercer et al 1977; Thompson 1984) in a solution of hydrochloric acid, $50 \mathrm{gpl}$ stannous chloride and $20 \mathrm{gpl}$ antimony chloride, dried and weighed. The authenticity of data was ascertained by reported measurements.

Experimental set up for polarization measurements consisted of potentiostat/galvanostat, model CL-95 of Elico with a sweep generator. Saturated calomel electrode was used as reference electrode. The variation of the cast iron electrode potential under open circuit conditions in the tested solution were also determined after definite period of time and subsequently anodic and cathodic potentiostatic polarization curves were drawn. All electrochemical studies were made at $28 \pm 1^{\circ} \mathrm{C}$ and in each experiment $500 \mathrm{~mL}$ of test solution was employed (Wahab El abd and Din El Shams 1978).

Results of polarization and weight loss measurement for corrosive medium have been carried out for $\mathrm{NaCl}-600$ ppm, $\mathrm{KCl}-600$ ppm, $\mathrm{Na}_{2} \mathrm{SO}_{4}-400$ ppm, $\mathrm{CaCO}_{3}-$ 400 ppm, $\mathrm{CaCl}_{2}-120$ ppm, $\mathrm{MgSO}_{4} 150$ ppm, $\mathrm{NaNO}_{3}-$ 
$65 \mathrm{ppm}, \mathrm{MnSO}_{4}-5 \mathrm{ppm}, \mathrm{Pb}\left(\mathrm{NO}_{3}\right)_{2}-3 \mathrm{ppm}, \mathrm{KBr}-5 \mathrm{ppm}$ and $\mathrm{KI}-5 \mathrm{ppm}$. These will be referred to in the text as A, B, C, D, E, F, G, H, I, J, K, L. In order to determine the average contribution of each salt to the corrosion rate, a test solution containing all above salts was prepared for the study. Redistilled water was used in the preparation of all test solutions. All chemicals used were of analytical grade.

\section{Results and discussion}

The corrosion rate of cast iron in the test solutions was calculated from decrease in weight observed in coupons in weight loss tests using following formula

$$
\text { Corr. rate }(\mathrm{mpy})=\frac{534 \times w}{D \times A \times T},
$$

where $w$ is weight loss $(\mathrm{mg}), D$ the density $\left(\mathrm{g} / \mathrm{cm}^{2}\right), A$ the exposed area of specimen $\left(\mathrm{inch}^{2}\right), T$ the time of exposure (h).
For potentiostatic measurements potentiostatic parameters $I_{\text {corr }}, E_{\text {corr }}$ were obtained from the slopes of linear polarization curves and corrosion rate was calculated using the following expression

$$
\text { Corr. rate }(\mathrm{mpy})=\frac{0 \cdot 129 \times I_{\text {corr }} \times E W}{D \times A},
$$

where $I_{\text {corr }}$ is corrosion current $(A), E W$ the equivalent weight of metal $(\mathrm{g}), A$ the exposed area of specimens $\left(\mathrm{cm}^{2}\right), D$ the density of metal $\left(\mathrm{g} / \mathrm{cm}^{2}\right)$ (Vashi and Champaneri 1997; Mehra and Soni 2001).

The corrosion rate was converted from mpy to mmpy using following relation

$$
1 \mathrm{mpy}=0.0254 \mathrm{mmpy} \text {. }
$$

Table 1 gives the composition of various test solutions taken for the study. Table 2 shows the results of weight

\begin{tabular}{|c|c|c|c|c|c|c|c|c|c|c|c|c|c|c|}
\hline \multirow[b]{2}{*}{ Component } & \multirow{2}{*}{$\begin{array}{c}\text { Concen- } \\
\text { tration } \\
(\mathrm{ppm})\end{array}$} & \multicolumn{13}{|c|}{ Ion concentration (ppm) } \\
\hline & & $\mathrm{Na}^{+}$ & $\mathrm{K}^{+}$ & $\mathrm{Ca}^{2+}$ & $\mathrm{Mg}^{2+}$ & $\mathrm{Pb}^{2+}$ & $\mathrm{Mn}^{2+}$ & $\mathrm{Cl}^{-}$ & $\mathrm{SO}_{4}^{2-}$ & $\mathrm{HCO}_{3}^{-}$ & $\mathrm{CO}_{3}^{2-}$ & $\mathrm{NO}_{3}^{2-}$ & $\mathrm{Br}^{-}$ & $\mathrm{I}^{-}$ \\
\hline $\mathrm{NaCl}$ & 600 & $236 \cdot 0$ & - & - & - & - & - & $364 \cdot 0$ & - & - & - & - & - & - \\
\hline $\mathrm{KCl}$ & 600 & - & $314 \cdot 7$ & - & - & - & - & $285 \cdot 3$ & - & - & - & - & - & - \\
\hline $\mathrm{Na}_{2} \mathrm{SO}_{4}$ & 400 & $129 \cdot 5$ & - & - & - & - & - & - & $270 \cdot 5$ & - & - & - & - & - \\
\hline $\mathrm{CaCO}_{3}$ & 400 & - & - & $160 \cdot 2$ & - & - & - & - & - & - & $239 \cdot 8$ & - & - & - \\
\hline $\mathrm{CaCl}_{2}$ & 120 & - & - & $43 \cdot 3$ & - & - & - & $76 \cdot 7$ & - & - & - & - & - & - \\
\hline $\mathrm{MgSO}_{4}$ & 150 & - & - & - & $30 \cdot 3$ & - & - & - & $119 \cdot 7$ & - & - & - & - & - \\
\hline $\mathrm{NaHCO}_{3}$ & 400 & $109 \cdot 5$ & - & - & - & - & - & - & - & $290 \cdot 5$ & - & - & - & - \\
\hline $\mathrm{NaNO}_{3}$ & 65 & $17 \cdot 6$ & - & - & - & - & - & - & - & - & - & $47 \cdot 4$ & - & - \\
\hline $\mathrm{MnSO}_{4}$ & 5 & - & - & - & - & - & 1.8 & - & $3 \cdot 2$ & - & - & - & - & - \\
\hline $\mathrm{Pb}\left(\mathrm{NO}_{3}\right)_{2}$ & 3 & - & - & - & - & $1 \cdot 9$ & - & - & - & - & - & $1 \cdot 1$ & - & - \\
\hline $\mathrm{KBr}$ & 5 & - & 1.6 & - & - & - & - & - & - & - & - & - & $3 \cdot 4$ & - \\
\hline KI & 5 & - & $1 \cdot 2$ & - & - & - & - & - & - & - & - & - & - & $3 \cdot 8$ \\
\hline $\begin{array}{l}\text { Composite } \\
\text { water }\end{array}$ & Total & $492 \cdot 6$ & $317 \cdot 5$ & $203 \cdot 5$ & $30 \cdot 3$ & $1 \cdot 9$ & $1 \cdot 8$ & $726 \cdot 0$ & $393 \cdot 4$ & $290 \cdot 5$ & $239 \cdot 8$ & $48 \cdot 5$ & $3 \cdot 4$ & $3 \cdot 8$ \\
\hline
\end{tabular}
loss obtained by NACE standard TM-01-69 method for

Table 1. Composition of various test solutions and composite water.

\begin{tabular}{|c|c|c|c|c|c|c|}
\hline \multirow[b]{2}{*}{ Solution } & \multicolumn{6}{|c|}{ Weight loss $\left(\mathrm{mg} / \mathrm{dm}^{2} \pm\right.$ S.D. $)$} \\
\hline & $24 \mathrm{~h}$ & $72 \mathrm{~h}$ & $120 \mathrm{~h}$ & $192 \mathrm{~h}$ & $240 \mathrm{~h}$ & $360 \mathrm{~h}$ \\
\hline $\mathrm{NaCl}$ & $15 \cdot 416 \pm 0 \cdot 72$ & $47 \cdot 125 \pm 0 \cdot 45$ & $84 \cdot 166 \pm 1 \cdot 19$ & $139 \cdot 666 \pm 2 \cdot 76$ & $176 \cdot 666 \pm 11 \cdot 1$ & $278 \cdot 333 \pm 7 \cdot 20$ \\
\hline $\mathrm{KCl}$ & $14 \cdot 916 \pm 0 \cdot 44$ & $44 \cdot 833 \pm 0.52$ & $79 \cdot 166 \pm 0 \cdot 48$ & $137 \cdot 916 \pm 5 \cdot 75$ & $170 \cdot 333 \pm 5 \cdot 40$ & $269 \cdot 166 \pm 6 \cdot 62$ \\
\hline $\mathrm{Na}_{2} \mathrm{SO}_{4}$ & $6 \cdot 499 \pm 0 \cdot 28$ & $27 \cdot 249 \pm 0 \cdot 08$ & $52 \cdot 249 \pm 1 \cdot 26$ & $87 \cdot 493 \pm 2 \cdot 42$ & $119 \cdot 499 \pm 9 \cdot 20$ & $171 \cdot 666 \pm 4 \cdot 46$ \\
\hline $\mathrm{CaCO}_{3}$ & $5 \cdot 249 \pm 0 \cdot 18$ & $19 \cdot 499 \pm 2 \cdot 43$ & $31.916 \pm 0.96$ & $42 \cdot 833 \pm 0 \cdot 83$ & $53 \cdot 416 \pm 2 \cdot 78$ & $67 \cdot 083 \pm 1 \cdot 04$ \\
\hline $\mathrm{CaCl}_{2}$ & $2 \cdot 916 \pm 0 \cdot 05$ & $13 \cdot 166 \pm 0 \cdot 08$ & $29 \cdot 083 \pm 0 \cdot 08$ & $68 \cdot 833 \pm 1 \cdot 24$ & $73 \cdot 166 \pm 1 \cdot 54$ & $89 \cdot 666 \pm 3 \cdot 16$ \\
\hline $\mathrm{MgSO}_{4}$ & $3 \cdot 083 \pm 0 \cdot 02$ & $13 \cdot 500 \pm 0 \cdot 05$ & $25 \cdot 500 \pm 0 \cdot 28$ & $47 \cdot 666 \pm 0 \cdot 30$ & $60 \cdot 583 \pm 0 \cdot 30$ & $79 \cdot 916 \pm 3.42$ \\
\hline $\mathrm{NaHCO}_{3}$ & $5 \cdot 916 \pm 0 \cdot 28$ & $25 \cdot 416 \pm 0 \cdot 64$ & $42 \cdot 500 \pm 1 \cdot 50$ & $56 \cdot 416 \pm 1 \cdot 14$ & $69 \cdot 750 \pm 2 \cdot 76$ & $89 \cdot 666 \pm 3 \cdot 16$ \\
\hline $\mathrm{NaNO}_{3}$ & $1 \cdot 249 \pm 0 \cdot 00$ & $5.249 \pm 0.02$ & $10 \cdot 499 \pm 0 \cdot 50$ & $17.499 \pm 0.58$ & $21.917 \pm 0.60$ & $39 \cdot 583 \pm 0 \cdot 30$ \\
\hline $\mathrm{MnSO}_{4}$ & $0 \cdot 000 \pm 0 \cdot 00$ & $0 \cdot 416 \pm 0 \cdot 06$ & $1.499 \pm 0 \cdot 05$ & $4 \cdot 000 \pm 0 \cdot 62$ & $6 \cdot 749 \pm 0 \cdot 12$ & $9 \cdot 749 \pm 0 \cdot 36$ \\
\hline $\mathrm{Pb}\left(\mathrm{NO}_{3}\right)_{2}$ & $0 \cdot 000 \pm 0 \cdot 00$ & $0 \cdot 583 \pm 0 \cdot 01$ & $3 \cdot 000 \pm 0 \cdot 01$ & $4 \cdot 083 \pm 0 \cdot 18$ & $4 \cdot 499 \pm 0 \cdot 44$ & $4 \cdot 499 \pm 0 \cdot 42$ \\
\hline $\mathrm{KBr}$ & $0.083 \pm 0.01$ & $3 \cdot 333 \pm 0.12$ & $5 \cdot 666 \pm 0 \cdot 20$ & $9.749 \pm 0.03$ & $12.49 \pm 0.78$ & $19.416 \pm 0.82$ \\
\hline $\mathrm{KI}$ & $0 \cdot 083 \pm 0 \cdot 01$ & $3 \cdot 000 \pm 0 \cdot 16$ & $5 \cdot 000 \pm 0 \cdot 53$ & $9 \cdot 166 \pm 0.57$ & $11 \cdot 916 \pm 0.76$ & $18.666 \pm 0.68$ \\
\hline $\begin{array}{c}\text { Composite } \\
\text { water }\end{array}$ & $67 \cdot 416 \pm 2.66$ & $210.583 \pm 9.37$ & $368 \cdot 333 \pm 11 \cdot 15$ & $598.083 \pm 14.72$ & $761 \cdot 583 \pm 17 \cdot 17$ & $1146 \cdot 080 \pm 22 \cdot 46$ \\
\hline
\end{tabular}

Table 2. Effect of time of exposure on weight loss $\left(\mathrm{mg} / \mathrm{dm}^{2}\right)$ in different test solutions at $28 \pm 1{ }^{\circ} \mathrm{C}$ for cast iron. 
cast iron for different durations of exposure in different aqueous salt solutions. An increase in value of loss in weight was observed. The corrosion of cast iron in various aqueous salt solutions was in the order of $\mathrm{A}>\mathrm{B}>\mathrm{C}>$ $\mathrm{G}>\mathrm{D}>\mathrm{F}>\mathrm{E}>\mathrm{H}>\mathrm{L} \cong \mathrm{K}>\mathrm{J} \cong \mathrm{I}$ for $24 \mathrm{~h}, \mathrm{~A}>\mathrm{B}>\mathrm{C}$ $>\mathrm{G}>\mathrm{D}>\mathrm{F}>\mathrm{E}>\mathrm{H}>\mathrm{L}>\mathrm{K}>\mathrm{J}>\mathrm{I}$ for $72 \mathrm{~h}, \mathrm{~A}>\mathrm{B}>\mathrm{C}>$ $\mathrm{G}>\mathrm{D}>\mathrm{E}>\mathrm{F}>\mathrm{H}>\mathrm{L}>\mathrm{K}>\mathrm{J}>\mathrm{I}$ for $120 \mathrm{~h}, \mathrm{~A}>\mathrm{B}>\mathrm{C}>$ $\mathrm{E}>\mathrm{G}>\mathrm{F}>\mathrm{D}>\mathrm{H}>\mathrm{K}>\mathrm{L}>\mathrm{J}>\mathrm{I}$ for $192 \mathrm{~h}, \mathrm{~A}>\mathrm{B}>\mathrm{C}$ $>\mathrm{E}>\mathrm{G}>\mathrm{F}>\mathrm{D}>\mathrm{H}>\mathrm{K}>\mathrm{L}>\mathrm{I}>\mathrm{J}$ for $240 \mathrm{~h}$ and $\mathrm{A}>\mathrm{B}$ $>\mathrm{C}>\mathrm{E} \cong \mathrm{G}>\mathrm{F}>\mathrm{D}>\mathrm{H}>\mathrm{K}>\mathrm{L}>\mathrm{I}>\mathrm{J}$ for $360 \mathrm{~h}$. Although for all durations order of variation in corrosion rate of cast iron remains the same for $\mathrm{NaCl}, \mathrm{KCl}, \mathrm{Na}_{2} \mathrm{SO}_{4}, \mathrm{NaNO}_{3}$, however, it changes significantly for $\mathrm{CaCO}_{3}, \mathrm{CaCl}_{2}$, $\mathrm{MgSO}_{4}, \mathrm{NaHCO}_{3}, \mathrm{MnSO}_{4}, \mathrm{~Pb}\left(\mathrm{NO}_{3}\right)_{2}, \mathrm{KBr}$ and $\mathrm{KI}$. The two anions that are reported to have a significant influence on the corrosion characteristics of cast iron are chloride and sulphate ions. The relative increase is $0 \cdot 204$ times for $\mathrm{NaCl}, 0.203$ times for $\mathrm{KCl}, 0.761$ times for $\mathrm{Na}_{2} \mathrm{SO}_{4}, 0 \cdot 148$ times for $\mathrm{CaCO}_{3}, 1.049$ times for $\mathrm{CaCl}_{2}$, 0.728 times for $\mathrm{MgSO}_{4}, 0 \cdot 010$ times for $\mathrm{NaHCO}_{3}, 1 \cdot 111$ times for $\mathrm{NaNO}_{3}, 0 \cdot 130$ times for $\mathrm{MnSO}_{4}, 0 \cdot 060$ times for $\mathrm{Pb}\left(\mathrm{NO}_{3}\right)_{2}, 14.556$ times for $\mathrm{KBr}, 13.958$ times for $\mathrm{KI}$ from $24 \mathrm{~h}$ to $360 \mathrm{~h}$ duration. The relative increase in corrosion rate is less because of neutral or slightly basic nature of salts (Foley 1978). The major effect on cast iron is due to adsorption behaviour of anions of the electrolyte at the electrode surface.

It is clear from table 2 that metal loss increases progressively with time solutions but corrosion rate does not follow a definite trend for all test solutions and is not proportional with time, solutions being of different nature and present in different concentrations. The corrosion rate of cast iron in $\mathrm{NaCl}, \mathrm{KCl}, \mathrm{Na}_{2} \mathrm{SO}_{4}, \mathrm{CaCl}_{2}, \mathrm{NaNO}_{3}$, $\mathrm{MnSO}_{4}, \mathrm{KBr}$, KI increase continuously with immersion period while in the $\mathrm{CaCO}_{3}, \mathrm{MgSO}_{4}, \mathrm{NaHCO}_{3}$ and $\mathrm{Pb}\left(\mathrm{NO}_{3}\right)_{2}$ test solutions the corrosion rate increase is followed by a decrease after some period. This may be because of anions accelerator and inhibitor behaviour caused by stability of ferric oxide film formed after corrosion reaction. The relative increase in halide ions salts is found to be more than other ions because of corrosive nature of halide ions than sulphate and nitrate ions.

The initial rate of corrosion is high for $\mathrm{NaCl}$ and $\mathrm{KCl}$ and the relative increase in corrosion rate is less as the reaction proceeds, because there remains no direct contact between metal surface and corrosive ions by corrosion product and excess of cations nearby the metal surface. On the other hand in the $\mathrm{KBr}$ and $\mathrm{KI}$ test solutions the initial corrosion rate is less due to non availability of anions at the metal surface. After initiation of reaction,

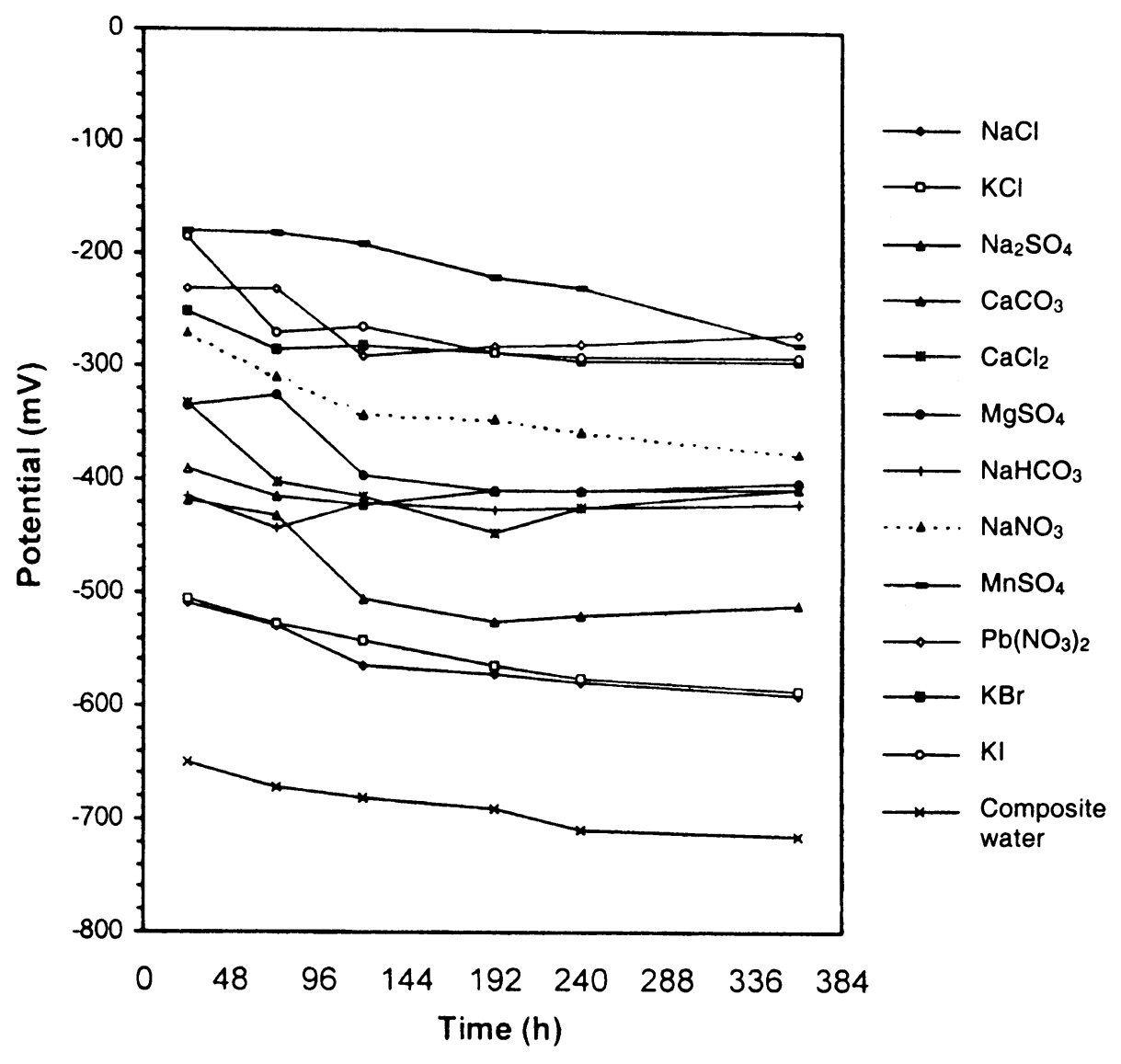

Figure 1. Potential vs time curves for cast iron in different test solutions and composite water. 
the rate increases continuously and is not hindered by corrosion as in the case of $\mathrm{KCl}, \mathrm{NaCl}$ and $\mathrm{CaCl}_{2}$. The negative increase in $\mathrm{CaCO}_{3}$ and less increase in $\mathrm{NaHCO}_{3}$ of corrosion rate indicates the non corrosive behaviour of $\mathrm{CaCO}_{3}$ and $\mathrm{NaHCO}_{3}$ because of less mobility of $\mathrm{Ca}^{2+}$ and $\mathrm{HCO}_{3}^{-}$ions (Chandra et al 1994; Hammout et al 1995). These results cannot be compared with earlier studies as they correspond to high anionic concentrations. The average contribution of these salts to corrosion rate in potable water is $24.20 \%$ for $\mathrm{NaCl}, 23.32 \%$ for $\mathrm{KCl}$, $14.15 \%$ for $\mathrm{Na}_{2} \mathrm{SO}_{4}, 7.98 \%$ for $\mathrm{CaCO}_{3}, 8 \cdot 14 \%$ for $\mathrm{CaCl}_{2}$, $7.04 \%$ for $\mathrm{MgSO}_{4}, 10.22 \%$ for $\mathrm{NaHCO}_{3}, 2.83 \%$ for $\mathrm{NaNO}_{3}, 0.50 \%$ for $\mathrm{MnSO}_{4}, 0.46 \%$ for $\mathrm{Pb}\left(\mathrm{NO}_{3}\right)_{2}, 1.39 \%$ for $\mathrm{KBr}$ and $1.29 \%$ for $\mathrm{KI}$ from $24 \mathrm{~h}$ to $360 \mathrm{~h}$ duration of immersion.

The specimens immersed in the different test solutions develop the open circuit potential as $-590 \mathrm{mV}$ for $\mathrm{NaCl}$, $-587 \mathrm{mV}$ for $\mathrm{KCl},-512 \mathrm{mV}$ for $\mathrm{Na}_{2} \mathrm{SO}_{4},-408 \mathrm{mV}$ for $\mathrm{CaCO}_{3},-408 \mathrm{mV}$ for $\mathrm{CaCl}_{2},-402 \mathrm{mV}$ for $\mathrm{MgSO}_{4}$, $-420 \mathrm{mV}$ for $\mathrm{NaHCO}_{3},-376 \mathrm{mV}$ for $\mathrm{NaNO}_{3},-227 \mathrm{mV}$ for $\mathrm{MnSO}_{4},-280 \mathrm{mV}$ for $\mathrm{Pb}\left(\mathrm{NO}_{3}\right)_{2},-295 \mathrm{mV}$ for $\mathrm{KBr}$, $-290 \mathrm{mV}$ for $\mathrm{KI},-715 \mathrm{mV}$ for composite water. The variation of OCP with time have been given in figure 1, which depicts an inverse relationship with corrosion rate. The OCP in all test solutions regardless of their nature, shift towards negative (less noble) direction with the passage of immersion period and finally attain steady state in $\sim 360 \mathrm{~h}$. Further, figure 1 shows that steady state potential for different test solutions are in the order $\mathrm{A}<\mathrm{B}<\mathrm{G}<\mathrm{E} \cong \mathrm{D}<\mathrm{H}<\mathrm{K}<\mathrm{L}<\mathrm{J}<$ I which support the corrosion rate order for $360 \mathrm{~h}$ duration of immersion.

Anodic and cathodic polarization plots for cast iron in different test solutions are furnished in figure 2 . The values of $I_{\text {corr }}$, Tafel slopes and OCP for various test solutions calculated from polarization curves have been given in table 3. Tafel curves show higher values for cathodic slopes than anodic due to the dissolution of anode into the test solution. The order of corrosion rate for cast iron in different test solutions observed by weight loss and potentiostatic polarization method is in good agreement but the corrosion rate calculated from potentiostatic method are higher than calculated from weight loss method. This is expected since corrosion rate is maximum in the beginning and decreases when

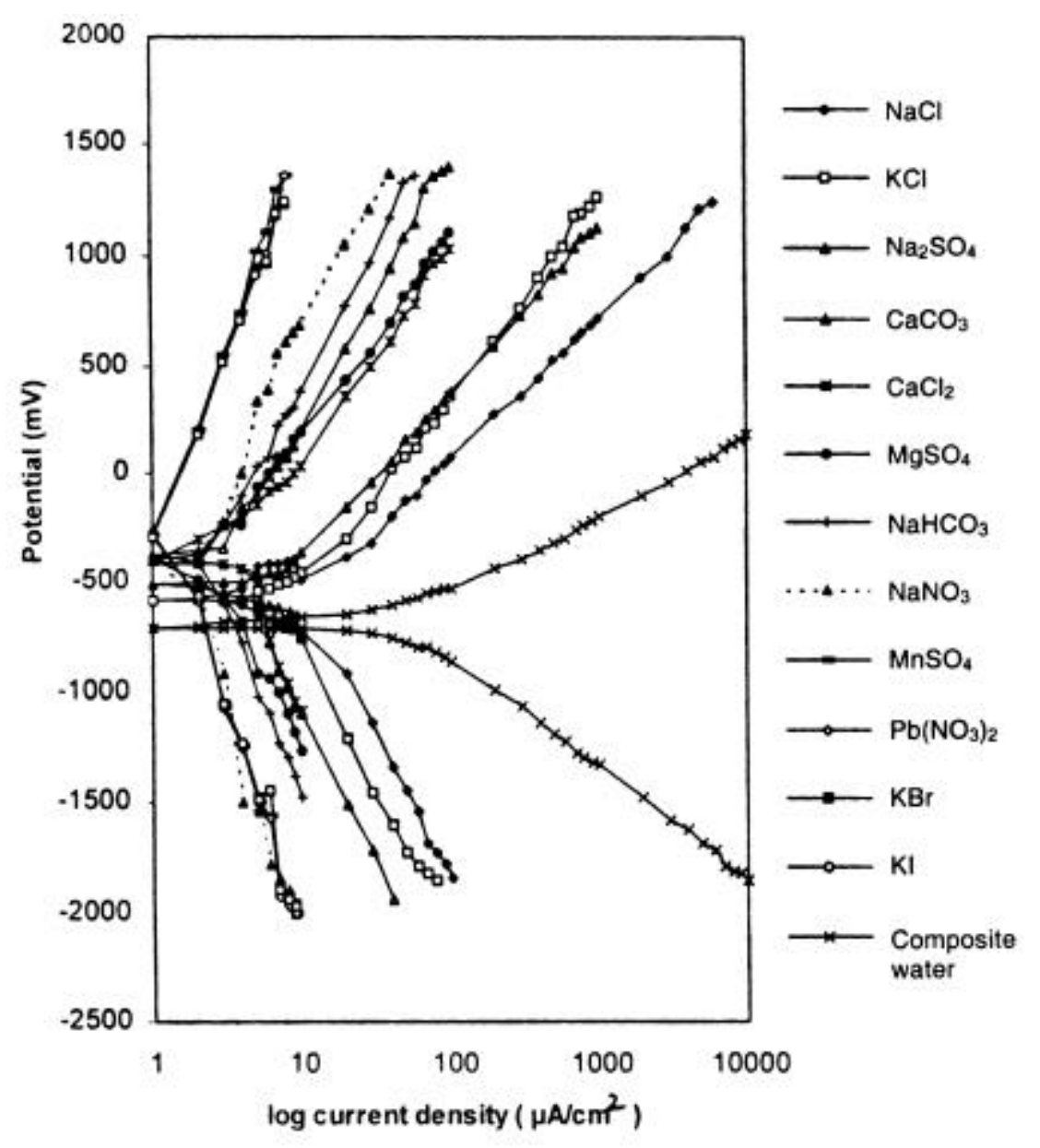

Figure 2. Potentiostatic polarization curves for cast iron in different test solutions and composite water for $360 \mathrm{~h}$. 
Table 3. Potentiostatic parameters for cast iron in different test solutions after $360 \mathrm{~h}$ duration of exposure at $28 \pm 1^{\circ} \mathrm{C}$.

\begin{tabular}{|c|c|c|c|c|c|c|}
\hline Solution & $\begin{array}{c}\text { OCP } \\
(-\mathrm{mV})\end{array}$ & $\begin{array}{l}I_{\text {corr. }} \\
(\mu \mathrm{A})\end{array}$ & $\begin{array}{c}\beta a \\
\text { (mV/decade) }\end{array}$ & $\begin{array}{c}\beta c \\
\text { (mV/decade) }\end{array}$ & $\begin{array}{l}\text { Corr. rate from } \\
\text { polari. data } \\
(\mathrm{mmpy})\end{array}$ & $\begin{array}{l}\text { Corr. rate from } \\
\text { wt. loss data } \\
\text { (mmpy) }\end{array}$ \\
\hline $\mathrm{KCl}$ & -590 & $11 \cdot 220$ & 58 & 120 & $0 \cdot 144$ & 0.095 \\
\hline $\mathrm{NaCl}$ & -587 & $10 \cdot 960$ & 62 & 127 & $0 \cdot 141$ & 0.092 \\
\hline $\mathrm{Na}_{2} \mathrm{SO}_{4}$ & -512 & $6 \cdot 607$ & 84 & 128 & $0 \cdot 085$ & $0 \cdot 058$ \\
\hline $\mathrm{CaCO}_{3}$ & -408 & $2 \cdot 138$ & 88 & 125 & $0 \cdot 027$ & 0.023 \\
\hline $\mathrm{CaCl}_{2}$ & -408 & $3 \cdot 631$ & 88 & 125 & $0 \cdot 046$ & $0 \cdot 030$ \\
\hline $\mathrm{MgSO}_{4}$ & -402 & $2 \cdot 692$ & 75 & 140 & $0 \cdot 034$ & $0 \cdot 027$ \\
\hline $\mathrm{NaHCO}_{3}$ & -420 & $2 \cdot 951$ & 96 & 140 & 0.038 & 0.030 \\
\hline $\mathrm{NaNO}_{3}$ & -376 & 1.479 & 120 & 140 & $0 \cdot 019$ & $0 \cdot 013$ \\
\hline $\mathrm{MnSO}_{4}$ & -280 & $0 \cdot 316$ & 168 & 190 & $0 \cdot 004$ & $0 \cdot 003$ \\
\hline $\mathrm{Pb}\left(\mathrm{NO}_{3}\right)_{2}$ & -270 & $0 \cdot 126$ & 160 & 170 & $0 \cdot 002$ & $0 \cdot 002$ \\
\hline $\mathrm{KBr}$ & -295 & $0 \cdot 794$ & 160 & 190 & $0 \cdot 010$ & 0.0065 \\
\hline KI & -290 & $0 \cdot 794$ & 160 & 194 & $0 \cdot 010$ & 0.0063 \\
\hline $\begin{array}{l}\text { Composite } \\
\text { water }\end{array}$ & -715 & $58 \cdot 88$ & 36 & 52 & 0.756 & $0 \cdot 389$ \\
\hline
\end{tabular}

equilibrium value is attained. But in contradiction to the previous studies (Smith 1980; Singh and Rao 1998), the corrosion rates obtained from potentiostatic measurements are not significantly high than those by weight loss measurements. Even in $\mathrm{CaCO}_{3}$ the corrosion rates are nearly similar. These observed results can be correlated with the small concentration of ions and small values of corrosion rates as compared to earlier studies (Koshel et al 1988).

According to Fontane for the more commonly used low $\mathrm{C}$ steel and steel alloy, $<1$ mpy is outstanding corrosion rate, 1-5 mpy is excellent, 5-20 mpy is good and can be used with caution, 20-50 mpy is fair and can be used for short exposure, 50-200 mpy is poor and above $200 \mathrm{ppm}$ completely unacceptable (Fontana 1986; Mehra and Soni 2002). However, these corrosion rates calculated are acceptable for long exposure. But the corrosion rates are due to a significant contribution of all salts available in water, hence best promising results can be obtained by decreasing corrosion due to each of the salt.

\section{Conclusions}

From the above results it is clear that anions play a decisive role in determining the ease with which cast iron undergoes dissolution upon application of some anodic current density. The order of corrosion in various salt solutions is $\mathrm{A}>\mathrm{B}>\mathrm{C}>\mathrm{G}>\mathrm{D}>\mathrm{F}>\mathrm{E}>\mathrm{H}>\mathrm{L} \cong \mathrm{K}>\mathrm{J} \cong \mathrm{I}$ for $24 \mathrm{~h}$, and $\mathrm{A}>\mathrm{B}>\mathrm{C}>\mathrm{E} \cong \mathrm{G}>\mathrm{F}>\mathrm{D}>\mathrm{H}>\mathrm{K}>\mathrm{L}>$ $\mathrm{I}>\mathrm{J}$ for $360 \mathrm{~h}$, i.e. halide ions contribute significantly to the corrosion rate of cast iron in potable water, sulphate and nitrate ions have intermediate effect and carbonate and bicarbonate have minimum contribution to corrosion of cast iron in potable water. Excellent corrosion resistance in the present investigation can be further upgraded to outstanding corrosion rate by inhibiting corrosion by
$72.24 \%$ for $\mathrm{NaCl}, 73 \cdot 15 \%$ for $\mathrm{KCl}, 56 \cdot 47 \%$ for $\mathrm{Na}_{2} \mathrm{SO}_{4}$, $00.00 \%$ for $\mathrm{CaCO}_{3}, 16.67 \%$ for $\mathrm{CaCl}_{2}, 6.51 \%$ for $\mathrm{MgSO}_{4}$, $16.65 \%$ for $\mathrm{NaHCO}_{3}, 00.00 \%$ for $\mathrm{NaNO}_{3}, 00.00 \%$ for $\mathrm{MnSO}_{4}, 00.00 \%$ for $\mathrm{Pb}\left(\mathrm{NO}_{3}\right)_{2}, 00.00 \%$ for $\mathrm{KBr}$ and $00.00 \%$ for $\mathrm{KI}$ individually. To decrease the corrosion rate of cast iron in composite potable water to an excellent corrosion resistance, the corrosion should be decreased by $67.40 \%$ using appropriate check measures and inhibitors.

\section{References}

Andrzejaczek B J 1979 Br. Corros. J. 14176

Chandra N, Konar J, Amrit Phala S S and Maneswar V B 1994 J. Electrochem. Soc. India $\mathbf{4 3} 175$

Dubey R S, Upadhyay D and Upadhyay S N 1997 Indian J. Chem. Technol. 4101

Foley R T 1978 Corrosion 2658

Fontana M G 1986 in Corrosion engineering (London: McGraw Hill Publication) 3rd ed., p. 172

Gedge G 1993 Proc. corrosion relat. aspect mater. potable water supplies (London: Arup \& Partners) p. 18

Gour B, Singh A K and Rao N 1994 Indian J. Chem. Technol. 1 225

Hammout B, Kortit S and Melhaovi A 1995 Bull. Electrochem. 11553

Jain S K 1986 An introduction to metallurgical analysis (Sahidabad: Vikas Publishing House Pvt. Ltd.) p. 153

Koshel K C, Bhatia J S, Shailendra K and Samant A K 1988 ONGC Bulletin 25115

Kumar V, Rao P and Patwardhan A K 1991 Tool Alloy Steels 25221

Mercer A D, Butler G and Gillian Wavren M 1977 Br. Corros. J. 12122

Rao B V S 1980 in Maintenance for reliability (Bombay: Media Promoters and Publishers Pvt. Ltd.) p. 137

Mehra R and Soni A 2001 J. Indian Council Chemist 18 22 
Mehra R and Soni A 2002 Indian J. Chem. Technol. 9473

Siiry P 1978 Br. Corros. J. 1331

Singh A K and Rao N J 1998 Indian J. Chem. Technol. 1 225

Smith D C 1980 Br. Corros. J. 15192

Thompson D H 1984 in Handbook of testing and evaluation (ed.) W H Ailor (New York: John Wiley) p. 136
Vashi R T and Champaneri V A 1997 Indian J. Chem. Technol. 4180

Vogel A I 1964 in Quantitative inorganic analysis (London: Longmans Green and Company Ltd.) p. 639

Wahab El abd F M and Din El Shams A M 1978 Br. Corros. J. 1339

Weber J 1979 Br. Corros. J. 1469 